\title{
Binding Modes of New Bis-Ru(II) Complexes to DNA: Effect of the Length of the Linker
}

\author{
Byung-Hyang Kwon, Byung-Hoon Choi, Hyun Mee Lee, Yoon Jung Jang, Jae-Cheol Lee, ${ }^{\dagger}$ and Seog K. Kim \\ Department of Chemistry, Yeungnam University, Gyeongsan City, Gyeong-buk 712-749, Korea \\ *E-mail:seogkim@yu.ac.kr \\ ${ }^{\dagger}$ Department of Food and Nutrition, Kangwon National University, Samcheok, Gangwon 245-711, Korea \\ Received February 1, 2010, Accepted April 2, 2010
}

\begin{abstract}
Bis-[dipyrido[3,2- $\left.a: 2^{\prime}, 3^{\prime}-c\right]$ phenazine $\left.)_{2}(1,10 \text {-phenanthroline })_{2} \mathrm{Ru}_{2}\right]^{2+}$ complexes (bis-Ru(II) complexes) tethered by linkers of various lengths were synthesized and their binding properties to DNA investigated by normal absorption and linear dichroism spectra, and fluorescence techniques in this study. Upon binding to DNA, the bis-Ru(II) complex with the longest linker (1,3-bis-(4-pyridyl)-propane), exhibited a negative LD $^{\mathrm{r}}$ signal whose intensity was as large as that in the DNA absorption region, followed by a complicate $\mathrm{LD}^{\mathrm{r}}$ signal in the metal-to-ligand charge transfer region. The luminescence intensity of this bis-Ru(II) complex was enhanced. The observed $\mathrm{LD}^{\mathrm{r}}$ and luminescence results resembled that of the $\left[\operatorname{Ru}(1,10 \text {-phenanthroline })_{2} \text { dipyrido[3,2-a:2',3'-c]phenazine }\right]^{2+}$ complex, whose dipyrido[3,2-a:2',3'-c]phenazine (dppz) ligand has been known to intercalate between DNA bases. Hence, it is conclusive that both dppz ligands of the bis- $\mathrm{Ru}$ (II) complex intercalate. The binding stoichiometry, however, was a single intercalated dppz per $\sim 2.3$ bases, which violates the "nearest binding site exclusion" model for intercalation. The length between the two Ru(II) complexes may be barely long enough to accommodate one DNA base between the two dppz ligands, but not for two DNA bases. When the linker was shorter (4,4'-bipyridine or 1,2-bis-(4-pyridyl)-ethane), the magnitude of the LD in the dppz absorption region, as well as the luminescence intensity of both bis-Ru(II) complexes, was half that of the bis-Ru(II) complex bearing a long linker. This observation can be elucidated by a model whereby one of the dppz ligands intercalates while the other is exposed to the aqueous environment.
\end{abstract}

Key Words: Bis-Ru(II) complex, Intercalation, DNA, Light switch effect, Polarized spectroscopy

\section{Introduction}

Interaction of one of the $\left[\mathrm{Ru}(1,10 \text {-phenanthroline })_{3}\right]^{2+}$ complex families, namely the $\left[\mathrm{Ru}(1,10 \text {-phenanthroline })_{2}\right.$ dipyrido[3,2$\left.a: 2^{\prime}, 3^{\prime}-c\right]$ phenazine $]^{2+}$ complex (hereafter referred to as $[\mathrm{Ru}(\mathrm{ph}-$ en) $\left.{ }_{2} \mathrm{dppz}\right]^{2+}$ ), with DNA, has been a subject of intense study due to its unique photophysical properties, binding modes, and potential application in biology. ${ }^{1}$ Upon binding to double-stranded DNA, the extended dppz ligand of the $\left[\mathrm{Ru}(\mathrm{phen})_{2} \mathrm{dppz}\right]^{2+}$ complex undoubtedly intercalates between the DNA base pairs, ${ }^{2-9}$ although the direction of insertion, whether from the major groove or minor groove, is still uncertain. As a result of intercalation, the water molecules are stripped from the dppz ligand, resulting in the "light switch effect" that denotes a remarkable enhancement in the luminescence intensity upon binding to double-stranded DNAs. ${ }^{6-9}$ It has been proposed that two energetically close metal-to-ligand charge transfer (MLCT) bands, whose relative energies are sensitive to environmental polarity, are responsible for the enhancement of luminescence intensity. ${ }^{10-13}$ Recently, a large enhancement of luminescence intensity upon binding to even single-stranded DNA has been reported. ${ }^{14-16}$ With single-stranded DNA, the formation of a cavity surrounding the $\left[\mathrm{Ru}(\mathrm{phen})_{2}\right.$ $\mathrm{dppz}]^{2+}$ complex and/or stacking of the dppz ligand between the DNA bases was proposed for the reason of the "turning on the light switch".

Interaction of the various bis-Ru(II) complexes with DNA has also been reported. ${ }^{17-23}$ The bis- $\mathrm{Ru}$ (II) complex in which the two $\left[\mathrm{Ru}(\mathrm{phen})_{2} \mathrm{dppz}\right]^{2+}$ complexes are connected by a rigid or semirigid linker, ${ }^{21-23}$ such as $\Delta, \Delta$ - and $\Lambda, \Lambda$ - $\left.[\mu \text {-(tatpp)(phen })_{4} \mathrm{Ru}_{2}\right]^{4+}$ (where tatpp $=9,11,22,29$-tetraazatetrapyrido[3,2-a:2' $3^{\prime}-c: 3^{\prime \prime}$,
2"-1:2"', 3 "'-n]pentacene), can intercalate between DNA base pairs in spite of their two bulky phenanthroline ligands at both ends. When bound to DNA, one of the Ru(II) locates in the minor groove of the DNA, while the other in the major groove. ${ }^{23}$ In contrast, when the two dppz moieties were connected by a flexi-

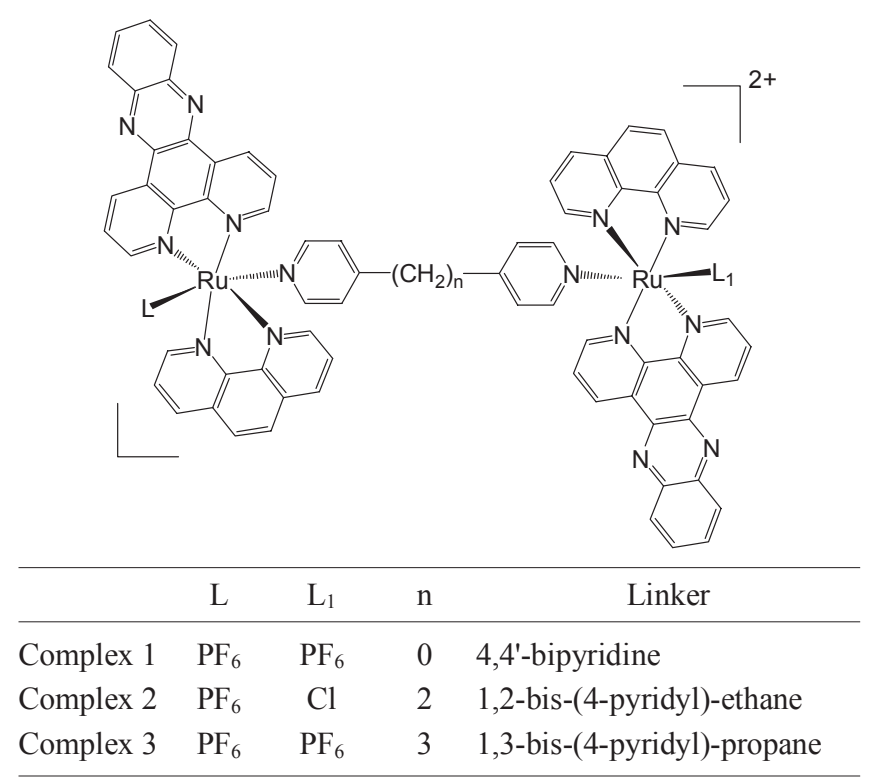

Scheme 1. Chemical structures of the $\left[\mu-(\right.$ linker $) \mathrm{L}_{2}$ (dipyrido[3,2$\left.a: 2^{\prime}, 3^{\prime}-c\right]$ phenazine $)_{2}$ (phenanthroline) $\left.{ }_{2} \mathrm{Ru}(\mathrm{II})_{2}\right]^{2+}$ with linkers: 4,4'bipyridine; 1,2-bis-(4-pyridyl)-ethane; 1,3-bis-(4-pyridyl)-propane, from the top, respectively. In the text, these molecules are denoted as complex 1,2 , and 3 , from the top. 
ble linker, the two Ru(II)s, ligated with two phenanthroline each, were located at the minor groove, with the linker situated in the major groove. ${ }^{21,22}$ Other type of the bis-Ru(II)dppz, in which the two $\mathrm{Ru}(\mathrm{II})$ units are tethered by a 4,4'-dipyridyl-1,5-pentane linker, with DNA have also been investigated by spectroscopic and thermodynamic study. It has been shown that at least one of the two dppz ligands intercalates between the DNA base-pairs. ${ }^{19}$ In this case, the linker is connected to the two $\mathrm{Ru}(\mathrm{II})$ complexes at the ligated pyridinium ring in lieu of the dppz ligands.

In this study, the synthesis and interaction of bis- $\mathrm{Ru}$ (II) complexes, chemical structures shown in Scheme 1, with native calf thymus DNA (hereafter referred to as DNA) are reported. As shown in the Scheme 1, two Ru(II) complexes, both possessing one intercalating dppz ligand, are connected by bridges of different lengths, thereby allowing effective investigation of the effects of the bridge on the binding mode of the two Ru(II) complexes. In the case of complex $\mathbf{1}$, the bridge is short and the intercalation of at least one of the dppz ligand will not be allowed while the bridge of complex $\mathbf{3}$ is long enough for intercalation of both dppz ligands. The effects of these binding modes on the "light switch effect", as well as the interaction between the two dppz ligands which are expected to be parallel in the case of complex $\mathbf{3}$ as a result of intercalation of both dppz ligands, were investigated in this study.

\section{Materials and Methods}

Synthesis of the $\left[\mu-(B)\left(P F_{6}\right)_{2}(d p p z)_{2}(\text { phen })_{2} R_{2}\right]^{2+}(B=b p y$, bpp) and $\left[\mu-(b p e)\left(\mathrm{PF}_{6}\right)(\mathrm{Cl})(\mathrm{dppz})_{2}-(\mathrm{phen})_{2} \mathrm{Ru}_{2}\right]^{2+}$ complexes. The starting materials, $\left[\mathrm{Ru}(\mathrm{phen})(\mathrm{dppz}) \mathrm{Cl}_{2}\right]$, were synthesized by a previously reported method. ${ }^{7,24} \mathrm{The}\left[\mathrm{Ru}(\mathrm{phen})(\mathrm{dppz}) \mathrm{Cl}_{2}\right]$ $(0.5 \mathrm{mmol}, 0.3173 \mathrm{~g})$ was dissolved in a $10 \mathrm{~mL}$ EtOH: $\mathrm{H}_{2} \mathrm{O}$ mixture $(1: 1, \mathrm{v} / \mathrm{v})$, and then a solution of $10 \mathrm{~mL}$ of an $\mathrm{EtOH}: \mathrm{H}_{2} \mathrm{O}$ mixture $(1: 1, \mathrm{v} / \mathrm{v})$ containing the appropriate bridge ligand, namely, 4,4'-bipyridine, 1,2-bis(4-pyridyl)ethane, or 1,3-bis(4-pyridyl)propane (hereafter referred to as bpy, bpe, and bpp, respectively) $(0.25 \mathrm{mmol})$ was added. The solution was heated at reflux for seven days. The resulting dark reddish-brown solution was cooled to room temperature and the solvent removed by evaporation and the residue dissolved in $\mathrm{EtOH}$ and evaporated again. The residue was then dissolved in hot $\mathrm{H}_{2} \mathrm{O}$ and centrifuged. The supernatant was collected and upon addition of aqueous ammonium hexafluorophosphate solution, produced an orange solid that was filtered, washed with diethyl ether, and dried in an oven $\left(50{ }^{\circ} \mathrm{C}\right)$. The orange solid was dissolved in acetonitrile and chromatographed on alumina $(20 \times 1 \mathrm{~cm})$ with acetonitrile as the eluent. The orange band was collected. Column separation was repeated for higher purity. The orange solution was concentrated by evaporation and precipitated with diethyl ether. The light reddish-orange solid was collected by filtration, washed with diethyl ether, and dried in an oven $\left(50{ }^{\circ} \mathrm{C}\right)$. All solids were then dissolved in acetone and tetrabutylammonium chloride in acetone was added to obtain a water-soluble compound. The light reddish-orange solid was filtered, washed with diethyl ether, and dried in an oven $\left(50^{\circ} \mathrm{C}\right)$. All solvents used in the process were dried using standard procedures. All reactions were carried out under an inert atmosphere.

Yield: $60 \mathrm{mg}$. [ $\mu$-(bpy) $\left.\left(\mathrm{PF}_{6}\right)_{2}(\mathrm{dppz})_{2}(\mathrm{phen})_{2} \mathrm{Ru}_{2}\right]\left(\mathrm{PF}_{6}\right)_{2}$ Ele- mental analysis calcd (\%) for $\mathrm{C}_{70} \mathrm{H}_{44} \mathrm{~N}_{14} \mathrm{P}_{4} \mathrm{~F}_{24} \mathrm{Ru}_{2}$ (1863.193): C 45.12, H 2.38, N 10.52; found: C 45.10, H 2.19, N 10.25. ${ }^{1} \mathrm{H}-\mathrm{NMR}\left(\left[\mu-(\mathrm{bpy})\left(\mathrm{PF}_{6}\right)_{2}(\mathrm{dppz})_{2}(\text { phen })_{2} \mathrm{Ru}_{2}\right]\left(\mathrm{PF}_{6}\right)_{2}, 600 \mathrm{MHz}\right.$, DMSO- $\left.d_{6}, 25{ }^{\circ} \mathrm{C}\right) \delta 9.62(\mathrm{dd}, 4 \mathrm{H}), 8.78(\mathrm{~d}, 2 \mathrm{H}), 8.51(\mathrm{~d}, 1 \mathrm{H})$, $8.37(\mathrm{dd}, 4 \mathrm{H}), 8.25(\mathrm{t}, 2 \mathrm{H}), 8.16(\mathrm{t}, 2 \mathrm{H}), 8.05(\mathrm{~d}, 2 \mathrm{H}), 7.93(\mathrm{dd}$, $4 \mathrm{H}), 7.88(\mathrm{dd}, 4 \mathrm{H}), 7.76(\mathrm{t}, 2 \mathrm{H}) .{ }^{19} \mathrm{~F}$ NMR $\left(\left[\mu-(\mathrm{bpy})\left(\mathrm{PF}_{6}\right)_{2}\right.\right.$ $\left.\left.(\mathrm{dppz})_{2}(\text { phen })_{2} \mathrm{Ru}_{2}\right]\left(\mathrm{PF}_{6}\right)_{2}, 600 \mathrm{MHz}, \mathrm{DMSO}-d_{6}, 25{ }^{\circ} \mathrm{C}\right) \delta$ 69.840, -71.099

Yield: $60 \mathrm{mg}$. [ $\mu$-(bpe $\left.)\left(\mathrm{PF}_{6}\right)(\mathrm{Cl})(\mathrm{dppz})_{2}(\text { phen })_{2} \mathrm{Ru}_{2}\right]\left(\mathrm{PF}_{6}\right)_{2}$ Elemental analysis calcd (\%) for $\mathrm{C}_{72} \mathrm{H}_{48} \mathrm{~N}_{14} \mathrm{ClP}_{3} \mathrm{~F}_{18} \mathrm{Ru}_{2}$ (1781.7392): C 48.54, H 2.72, N 11.01; found: C 48.04, H 2.36, $\mathrm{N}$ 11.21. ${ }^{1} \mathrm{H}-\mathrm{NMR}\left(\left[\mu-(\mathrm{bpe})\left(\mathrm{PF}_{6}\right)(\mathrm{Cl})(\mathrm{dppz})_{2}(\mathrm{phen})_{2} \mathrm{Ru}_{2}\right]\left(\mathrm{PF}_{6}\right)_{2}\right.$, $\left.600 \mathrm{MHz}, \mathrm{DMSO}-d_{6}, 25^{\circ} \mathrm{C}\right) \delta 9.62(\mathrm{dd}, 4 \mathrm{H}), 8.78(\mathrm{~d}, 2 \mathrm{H}), 8.52$ $(\mathrm{d}, 1 \mathrm{H}), 8.36(\mathrm{dd}, 4 \mathrm{H}), 8.25(\mathrm{t}, 2 \mathrm{H}), 8.16(\mathrm{t}, 2 \mathrm{H}), 8.05(\mathrm{~d}, 2 \mathrm{H})$, 7.91 (dd, 4H), 7.88 (dd, 4H), $7.76(\mathrm{t}, 2 \mathrm{H}), 2.08(\mathrm{t}, 2 \mathrm{H}) .{ }^{19} \mathrm{~F}-\mathrm{NMR}$ $\left(\left[\mu-(\mathrm{bpe})\left(\mathrm{PF}_{6}\right)(\mathrm{Cl})(\mathrm{dppz})_{2}(\mathrm{phen})_{2} \mathrm{Ru}_{2}\right]\left(\mathrm{PF}_{6}\right)_{2}, 600 \mathrm{MHz}, \mathrm{DM}-\right.$ $\left.\mathrm{SO}-d_{6}, 25^{\circ} \mathrm{C}\right) \delta-69.836,-71.095$

Yield: $90 \mathrm{mg}$. [ $\mu$-(bpp) $\left.\left(\mathrm{PF}_{6}\right)_{2}(\mathrm{dppz})_{2}(\mathrm{phen})_{2} \mathrm{Ru}_{2}\right]\left(\mathrm{PF}_{6}\right)_{2}$ Elemental analysis calcd (\%) for $\mathrm{C}_{73} \mathrm{H}_{50} \mathrm{~N}_{14} \mathrm{P}_{4} \mathrm{~F}_{24} \mathrm{Ru}_{2}$ (1905.2734): C 46.02, H 2.65, N 10.29; found: C 46.01, H 2.34, N 10.26. ${ }^{1} \mathrm{H}-\mathrm{NMR}\left(\left[\mu-(\mathrm{bpp})\left(\mathrm{PF}_{6}\right)_{2}(\mathrm{dppz})_{2}(\mathrm{phen})_{2} \mathrm{Ru}_{2}\right]\left(\mathrm{PF}_{6}\right)_{2}, 600 \mathrm{MHz}\right.$, $\left.\mathrm{CDCl}_{3}-d, 25^{\circ} \mathrm{C}\right) \delta 9.68(\mathrm{dd}, 4 \mathrm{H}), 8.71(\mathrm{~d}, 2 \mathrm{H}), 8.66(\mathrm{~d}, 1 \mathrm{H}), 8.58$ $(\mathrm{dd}, 4 \mathrm{H}), 8.46(\mathrm{t}, 2 \mathrm{H}), 8.14(\mathrm{t}, 2 \mathrm{H}), 8.11(\mathrm{~d}, 2 \mathrm{H}), 8.06(\mathrm{dd}, 4 \mathrm{H})$, 8.03 (dd, 4H), 7.926 (t, 2H), 2.34 (t. 2H), 1.01(t, 2H). ${ }^{19}$ F-NMR $\left(\left[\mu-(\mathrm{bpp})\left(\mathrm{PF}_{6}\right)_{2}(\mathrm{dppz})_{2}(\mathrm{phen})_{2} \mathrm{Ru}_{2}\right]\left(\mathrm{PF}_{6}\right)_{2}, 600 \mathrm{MHz}, \mathrm{CDCl}_{3}-d\right.$, $\left.25{ }^{\circ} \mathrm{C}\right) \delta-69.946,-71.207$

Other materials. Calf thymus DNA (referred to as DNA) was purchased from Worthington (Lakewood, NJ, USA) and purified by dissolution (exhaustive shaking at $4{ }^{\circ} \mathrm{C}$ ) in a $5.0 \mathrm{mM}$ cacodylate buffer at $\mathrm{pH} 7.0$, containing $100 \mathrm{mM} \mathrm{NaCl}$ and $1.0 \mathrm{mM}$ EDTA, followed by several rounds of dialysis at $4{ }^{\circ} \mathrm{C}$ against $5.0 \mathrm{mM}$ cacodylate buffer, $\mathrm{pH}$ 7.0. The latter buffer was used throughout this work. Other chemicals were purchased from Aldrich or Merck and used without purification. The mixing ratio, $R$, was defined by the ratio of the concentration of the dppz of the complex per DNA base or phosphate concentration. Therefore, for instance, $R=0.1$ indicates five bis- $\mathrm{Ru}(\mathrm{II}) \mathrm{com}$ plexes (or $10 \mathrm{dppz}$ moieties) per 100 DNA bases or phosphate. The concentrations of DNA and of complexes 1, 2, and $\mathbf{3}$ were determined spectrophotometrically using their proper extinction coefficients: $\varepsilon_{258 \mathrm{~nm}}=6700 \mathrm{M}^{-1} \mathrm{~cm}^{-1}$ for DNA; $\varepsilon_{372 \mathrm{~nm}}=31680$, 30110 , and $29680 \mathrm{M} \mathrm{cm}^{-1}$ for complex 1, 2, and 3, respectively.

Measurements. Measurement of normal absorption spectra and linear dichroism (LD) spectra has been described elsewhere. ${ }^{23}$ The reduced LD $\left(\mathrm{LD}^{\mathrm{r}}\right)$, defined by the ratio of measured LD to the isotropic absorption spectrum, ${ }^{25-27}$ and related to the angle between the DNA helical axis and electronic transition moment of the DNA-bound Ru(II) complexes, was analyzed based on a detailed discussion for the electronic transition moment of the $\left[\mathrm{Ru}(\mathrm{phen})_{2} \mathrm{dppz}\right]^{2+}$ complex reported by Lincoln et $a l .{ }^{28}$ Fluorescence measurements were performed on a FP-777 (Jasco, Tokyo, Japan). Excitation and emission wavelength were 440 and $606 \mathrm{~nm}$, respectively. Slit widths were 10/10 nm.

\section{Results}

Absorption and LD spectra. Absorption spectra of bis-Ru(II) complexes 1, 2, and $\mathbf{3}$ in the presence and absence of $100 \mu \mathrm{M}$ 


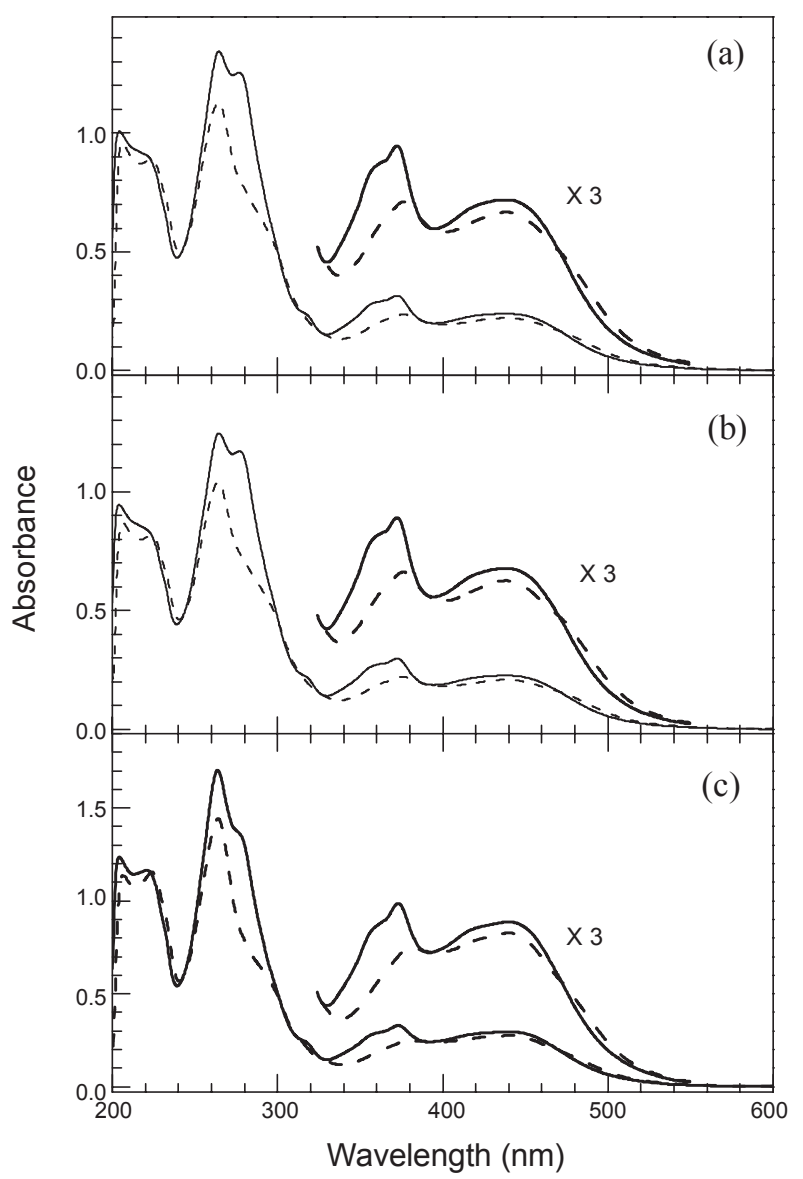

Figure 1. Representative absorption spectra of bis-Ru(II) complexes 1 (panel a), 2 (panel b), and $\mathbf{3}$ (panel c), in the presence (dashed curves) and absence (solid curves) of DNA. [DNA] $=100 \mu \mathrm{M}$, [complex] = $10.0 \mu \mathrm{M}$, which corresponds to $20.0 \mu \mathrm{M}$ of the dppz unit. The absorption spectra of DNA were subtracted and the spectra enlarged by 3 , shown at long wavelength for ease of comparison. The absorption spectra of the DNA-bound complexes at a concentration range below 10.0 $\mu \mathrm{M}(20.0 \mu \mathrm{M}$ in dppz) were identical for all three complexes.

DNA were recorded at complex concentrations of 2.0, 4.0, 6.0, $8.0,10.0 \mu \mathrm{M}$. The shapes of the absorption spectra were independent of the bis-Ru(II) complex, therefore, only that of 10.0 $\mu \mathrm{M} \mathrm{Ru}(\mathrm{II})$ complex $\mathbf{1}, \mathbf{2}$, and $\mathbf{3}(20.0 \mu \mathrm{M}$ in dppz) in the presence and absence of $100 \mu \mathrm{M}$ DNA are shown in Fig. 1 as an example. The absorption maxima at 360 and $370 \mathrm{~nm}$ correspond to the intraligand transition of dppz moieties, while the broad-band centered at $439 \mathrm{~nm}$ in the absence of DNA relates to the metalto-ligand transition (MLCT band). ${ }^{25}$ Although appearance of all three absorption spectra looked similar in the absence of DNA, the wavelength at which the absorption maxima were observed were similar, being $264,276,360$ (shoulder), 372 , and $439 \mathrm{~nm}$. However, there are slight differences between complexes with short linkers and the longest linker; absorption spectra of complexes 1 and $\mathbf{2}$ were identical, while different from that of complex 3. In the $250 \sim 300 \mathrm{~nm}$ wavelength region, the former two complexes produced two clear maxima, while that of complex 3 produced one maximum plus a shoulder.

The fact that the shape of the absorption spectra of all complexes upon association with DNA is independent of the complex

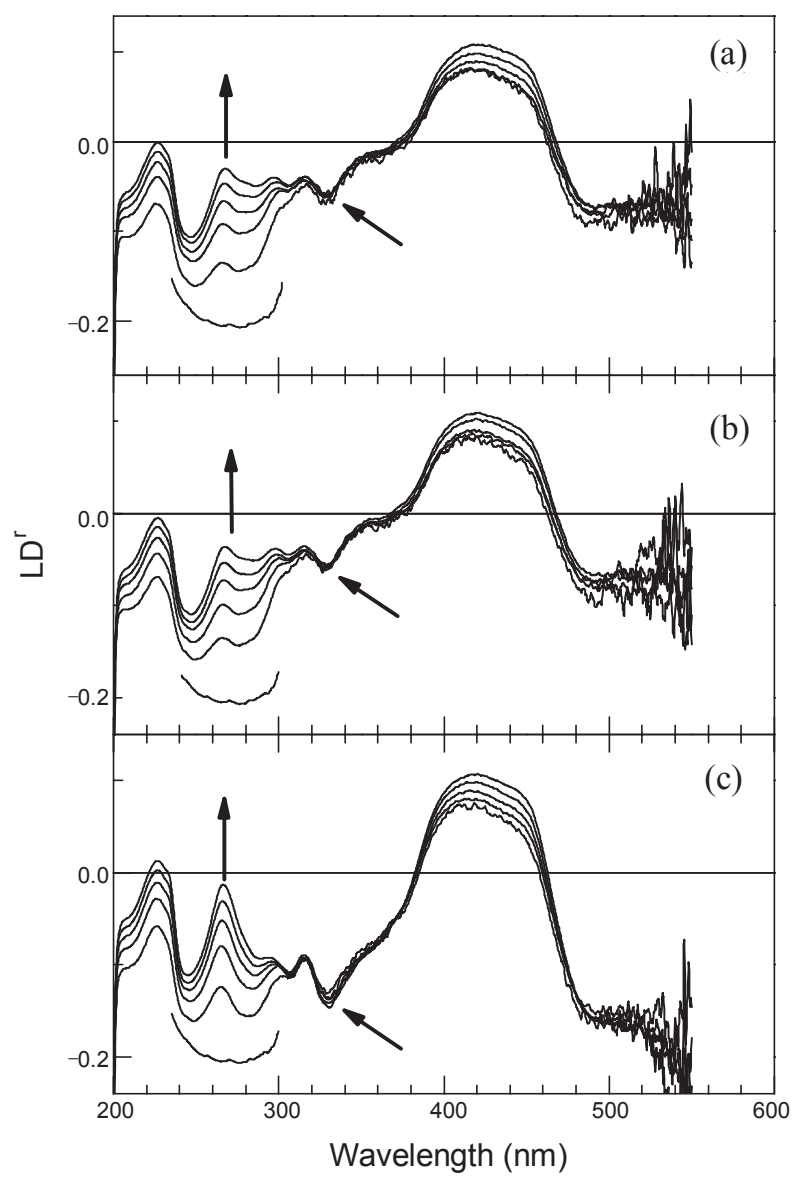

Figure 2. $\mathrm{LD}^{\mathrm{r}}$ spectra of the DNA-bound bis-Ru(II) complex $\mathbf{1}$ (panel a), $\mathbf{2}$ (panel b), and $\mathbf{3}$ (panel c). [DNA] $=100 \mu \mathrm{M}$, [complex] = 2.0, 4.0, $6.0,8.0,10.0 \mu \mathrm{M}(4.0,8.0,12.0,16.0,20.0 \mu \mathrm{M}$ in dppz). The magnitude of the $\mathrm{LD}^{\mathrm{r}}$ in the DNA absorption region $(\sim 260 \mathrm{~nm})$ decreased along the arrow direction as the concentration of the complex increased. The absorption band, corresponding to the electronic transition moment, lies along the long axis of the dppz ligand and is marked by arrows ( $~$ $329 \mathrm{~nm})$.

concentration suggests that the binding mode of complexes to DNA is homogeneous. An isosbestic point at $469 \mathrm{~nm}$ for complexes $\mathbf{1}$ and $\mathbf{2}$, and $466 \mathrm{~nm}$ for complex $\mathbf{3}$, also support the presence of one binding species. The UV-vis absorption spectra of complexes 1 and $\mathbf{2}$ appeared to be similar. Upon association with DNA, the dppz ligand absorption band at $372 \mathrm{~nm}$ shifted to a long wavelength by $3 \sim 4 \mathrm{~nm}$ for bis-Ru(II) complexes $\mathbf{1}$ and $\mathbf{2}$, and $\sim 8 \mathrm{~nm}$ for complex 3 . The hypochromism was $\sim 25 \%$ for all complexes. The hypochromism in the MLCT band was smaller compared to that in the dppz absorption region, being 7\% for all complexes. These observations suggest a strong interaction of the dppz ligand with the DNA bases. The origin of the alteration in the spectral properties between $200 \sim 300 \mathrm{~nm}$ may be the change in the bis-Ru(II) complex, or DNA, or both. Because DNA also absorbs in this region and is indistinguishable from that of the complex, the spectral change in this region will not be discussed further.

The $\mathrm{LD}^{\mathrm{r}}$ spectra of the bis-Ru(II) complex-DNA adducts, obtained by division of the measured LD spectrum by the normal absorption spectrum, $\operatorname{LD}^{\mathrm{r}}(\lambda)=\operatorname{LD}(\lambda) / \mathrm{A}(\lambda)$, are depicted in Fig. 


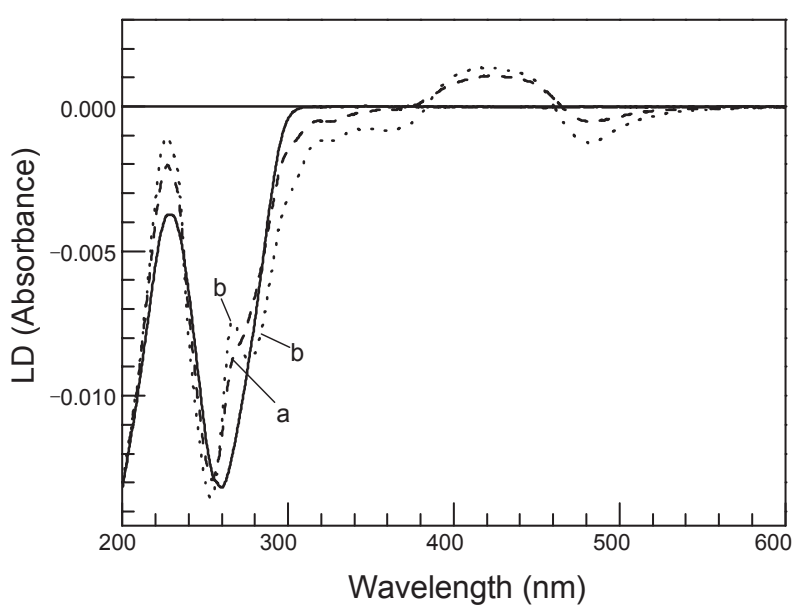

Figure 3. LD spectra of the DNA (solid curve), DNA-bound bis-Ru(II) complex $\mathbf{1}$ (dashed, curve a), and complex $\mathbf{3}$ (dotted, curve b). [DNA] = $100 \mu \mathrm{M}$, [complex] $=6.0 \mu \mathrm{M}(12.0 \mu \mathrm{M}$ in dppz).

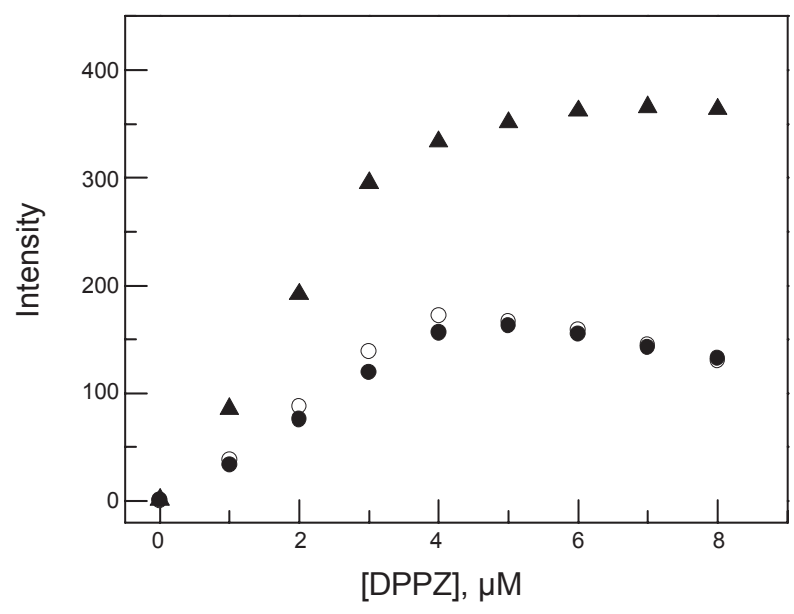

Figure 4. Increase in luminescence intensity of the bis-Ru(II) complexes with increasing complex concentration. Excitation and emission wavelength were 440 and $606 \mathrm{~nm}$, respectively. Slit widths were $10 / 10 \mathrm{~nm}$. [DNA] $=10 \mu \mathrm{M}$ in base or phosphate. Open and closed circles denote complexes $\mathbf{1}$ and $\mathbf{2}$, respectively. Triangles represent complex $\mathbf{3}$.

2. At a glance, the magnitude of the $\mathrm{LD}^{\mathrm{r}}$ in the DNA absorption region for all three complexes is easily noticeable. A positive contribution centered at $267 \mathrm{~nm}$ for complexes $\mathbf{1}$ and $\mathbf{2}$, and 265 $\mathrm{nm}$ for complex $\mathbf{3}$, are also noticed. Despite the positive contributions, decreases in the $\mathrm{LD}^{\mathrm{r}}$ magnitude in DNA absorption regions suggest that either DNA is bent upon binding of the bis-Ru(II) complexes, or the double strand dissociates near the binding site. In the complex $\mathbf{3}$ case, the magnitude at $329 \mathrm{~nm}$ at which the electric transition moment along the long in-plane symmetry axis of dppz ligand absorbs the radiation is comparable to that in the DNA absorption region, particularly at the low [bis-Ru(II) complex]:[DNA] ratio, suggesting that the dppz molecular plane is almost perpendicular to the DNA helical axis. In contrast, the $\mathrm{LD}^{\mathrm{r}}$ magnitude at $329 \mathrm{~nm}$ of complexes $\mathbf{1}$ and $\mathbf{2}$ are less than half, compared to that in the DNA absorption region. The $\mathrm{LD}^{\mathrm{r}}$ in the MLCT absorption region appeared to be complicate as observed for the mono-[Ru(phen $\left.)_{2} \mathrm{dppz}\right]^{2+}$ complex. ${ }^{7,25}$ Assuming the $\mathrm{LD}^{\mathrm{r}}$ value at $280 \mathrm{~nm}$ represents the DNA bases where the positive contribution from the ligand is negligible, the angle $(\alpha)$ of the dppz molecular plane of complex $\mathbf{3}$, with respect to the DNA helical axis, calculated from the equation: $\mathrm{LD}^{\mathrm{r}}=1.5 S\left(3 \cos ^{2} \alpha-1\right)$, was $85.5^{\circ}$ for the bis-Ru(II) complexDNA adduct at the lowest $\mathrm{Ru}(\mathrm{II})$ complex concentration. In the equation, $S$ is the orientation factor, reflecting the ability of DNA to orient, calculated by assuming an average angle of $86^{\circ}$ between the DNA base and helical axis. ${ }^{25,26}$ The average angles obtained from the same calculation were $\sim 63^{\circ}$ and $\sim 64^{\circ}$ for complexes $\mathbf{1}$ and $\mathbf{2}$ at the lowest concentration, respectively. It should be noted that as the concentration of the DNA-bound complex increases, decreases in the $\mathrm{LD}^{\mathrm{r}}$ magnitude in the DNA absorption region were observed for all three complexes while the magnitude in other wavelength regions, dppz absorption region and the MLCT band, are retained.

Figure 3 shows the LD spectrum of DNA, complex 1-DNA, and complex 3-DNA adducts. That of the complex 2-DNA adduct was identical to that of complex $\mathbf{1}$, and hence is not shown. In the DNA absorption region, complexes $\mathbf{1}$ and $\mathbf{2}$ exhibited some negative contributions in short wavelengths ( $c$ a. $235 \sim 250$ $\mathrm{nm}$ ), while at longer wavelengths, positive contributions were apparent (ca. 250 280 nm). In contrast, the LD of complex 3 in the long wavelength region consisted of positive and negative contributions, although the appearance of the LD in the short wavelength region was similar to that of complexes $\mathbf{1}$ and $\mathbf{2}$. The LD signal above $300 \mathrm{~nm}$ is also complicate and may be elucidated by the $\mathrm{LD}^{\mathrm{r}}$ spectrum. The point is that the overall magnitude of the LD spectrum of DNA does not seem to decrease by addition of the bis-Ru(II) complexes. Thus, decrease in the $\mathrm{LD}^{\mathrm{r}}$ magnitude in the DNA absorption region in Fig. 2 may be due to the large absorbance of the complexes (large denominator) in this region, rather than positive contributions of the ligands or the decrease in the orientation abilities of DNA.

Luminescence measurement. That luminescence intensity of the monomer $\left[\mathrm{Ru}(\mathrm{phen})_{2} \mathrm{dppz}\right]^{2+}$ complex increases upon binding to DNA has been well known and is denoted as the "light switch effect."2-9 A similar increase in the luminescence intensity was observed for all three complexes. At a constant DNA concentration, the luminescence intensities for the complexes increase almost proportionally to their concentrations (Fig. 4). The maximum was reached at a [complex]:[DNA] ratio of $\sim 0.4$ for complexes 1 and 2; further increase in complex concentration resulted in a slight decrease in intensity. Although the concentration ratio at the maximum was less clear for complex $\mathbf{3}$, it seemed to start to saturate at a [complex]:[DNA] ratio of $\sim 0.4$. In contrast with complexes $\mathbf{1}$ and $\mathbf{2}$, complex $\mathbf{3}$ did not produce a decrease in the luminescence intensity at high mixing ratios. The luminescence intensity of the DNA-bound complex $\mathbf{3}$ was about twice as high compared to those of complexes $\mathbf{1}$ and $\mathbf{2}$, suggesting that the environment of complex $\mathbf{1}$ and $\mathbf{2}$ were different from that of complex $\mathbf{3}$ near the binding site at DNA, or that the binding stoichiometry of the complexes is different. Although data are not shown to avoid complication, the luminescence intensity of the DNA-bound complex $\mathbf{3}$ at the maximum is comparable to that of the DNA-bound $r a c-\left[\mathrm{Ru}(\mathrm{phen})_{2} \mathrm{dppz}\right]^{2+}$ monomer at the same dppz concentration. 


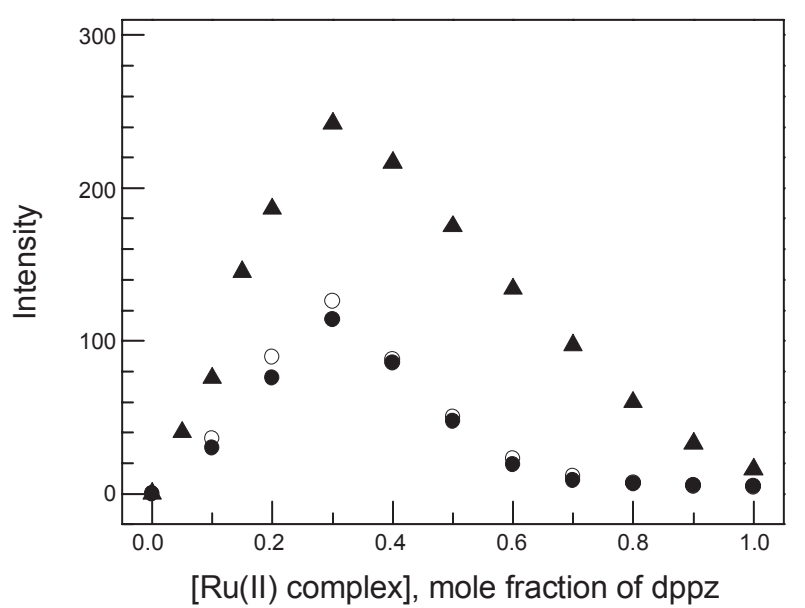

Figure 5. Change in luminescence intensity relative to the change in mole fraction of the bis-Ru(II) complexes (the Job plot). The mole fraction is in dppz unit. The conditions used to measure luminescence intensity are identical to those in Fig. 4.

The binding stoichiometry of the bis-Ru(II) complexes may be determined by the Job plot. When the luminescence intensity is used instead of absorbance change, the complex that changes in the luminescence characteristics upon binding to DNA is detected. From the absorption spectrum, the binding modes of the bis-Ru(II) complexes seem to be homogeneous, as well as the luminescence properties, thus the change in the luminescence intensity is well applicable to determine the binding stoichiometry. As depicted in Fig. 5, the maximum luminescence intensity was found at a dppz mole fraction of 0.3 for all complexes. This binding stoichiometry corresponds to one dppz ligand per 2.3 bases, or approximately one DNA base-pair, which is in contrast with the dppz mole fraction at a maximum of 0.2 found for the $\left[\mathrm{Ru}(\mathrm{phen})_{2} \mathrm{dppz}\right]^{2+}$ complex monomer. The stoichiometry of the $\left[\mathrm{Ru}(\mathrm{phen})_{2} \mathrm{dppz}\right]^{2+}$ complex to DNA is one complex (one dppz) per four DNA base or two base-pairs, and thus obeys the "nearest neighboring site exclusion model". Nevertheless, the stoichiometry found for the bis-Ru(II) complexes was not able to be explained by the "nearest neighboring site exclusion model". Further increase in the dppz mole fraction resulted in a decrease in the luminescence intensity for all complexes, due likely to self-quenching by overlying crowded $\mathrm{Ru}$ (II) complexes. The decreasing aspect of complex $\mathbf{3}$ upon increasing the dppz mole fraction is slightly different from those of complexes $\mathbf{1}$ and $\mathbf{2}$. In the case of both complexes $\mathbf{1}$ and $\mathbf{2}$, the intensity of luminescence reached zero at a mole fraction of 0.6 , corresponding to $1.5 \mathrm{dppz}$ per DNA base, while no zero luminescence intensity in the Job plot was found for complex $\mathbf{3}$, except in the case of a mole fraction of 0 or 1 . It should also be noted that the luminescence intensity of complexes $\mathbf{1}$ and $\mathbf{2}$, when associated with DNA at the maximum, is near half that of complex 3, as observed in Fig. 4.

\section{Discussion}

Binding properties of complex 3 to DNA. The change in spectral properties of complex $\mathbf{3}$ is summarized by hypochromi$\mathrm{sm}$ in all absorption ranges that is particularly pronounced in (a)
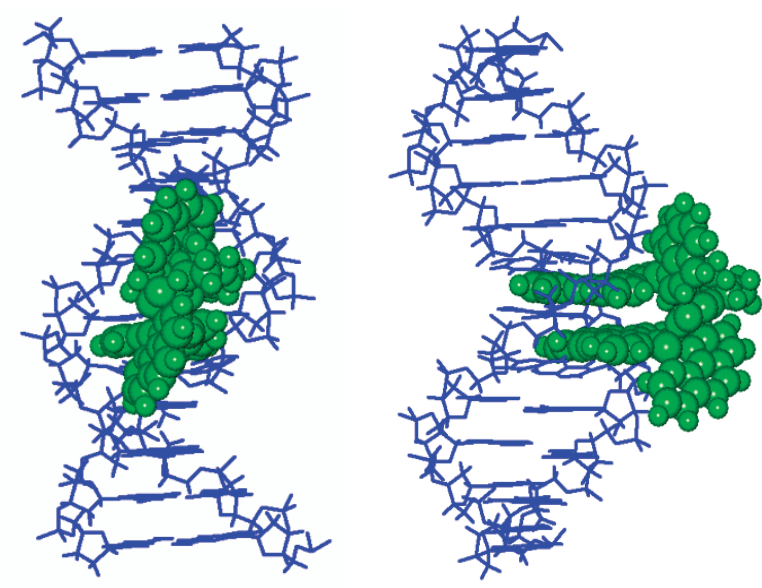

(b)
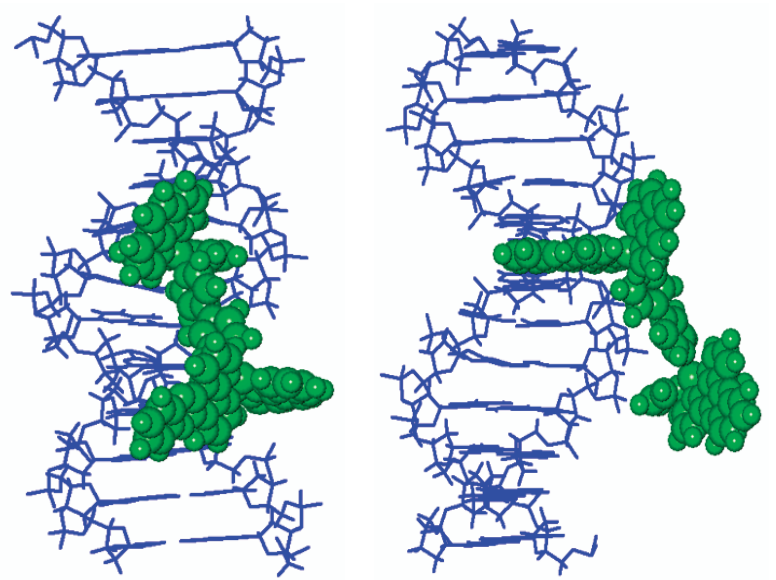

Figure 6. Schematic diagram of the bis-Ru(II) complex-DNA adduct. (a) Both the dppz ligand intercalates and one DNA base-pair is accommodated between dppz ligands as it is discussed for the complex $\mathbf{3}$ (upper diagrams). (b) One dppz is intercalated and the other exposed to the solvent (complex 1 and $\mathbf{2}$ case).

the dppz ligand absorption region, the negative $\mathrm{LD}^{\mathrm{r}}$ signal in the dppz ligand, whose magnitude is similar to that in the DNA absorption region, and followed by a complicate mixed positive and negative LD $^{r}$ in the MLCT band. Increase in luminescence intensity upon binding to DNA was also observed. The maximum luminescence intensity of complex $\mathbf{3}$ was comparable to that of the rac- $\left[\mathrm{Ru}(\mathrm{phen})_{2} \mathrm{dppz}\right]^{2+}$ complex at the same dppz concentration when bound to DNA. From $\mathrm{LD}^{\mathrm{r}}$, it is indicative that the long symmetry axis of both dppz ligands of complex $\mathbf{3}$, and thus the molecular plane of both dppz ligands, are near parallel to the DNA base plane (perpendicular to the DNA helical axis). Luminescence measurements indicated that both dppz ligand are protected from the water molecules and interact with the DNA bases at the binding site. All these observed spectral properties are indicative that both dppz ligands of complex $\mathbf{3}$ intercalate between the DNA base pairs. From the Job plot, the binding stoichiometry corresponds to $1 \mathrm{dppz}$ per $\sim 2.3$ bases, and thus one base pair is observed, violating the "nearest site exclusion model" for intercalation. This observation is in contrast with the intercalation of the rac- $\left[\mathrm{Ru}(\mathrm{phen})_{2} \mathrm{dppz}\right]^{2+}$ monomer, which obeys the model. The length of the linker of complex 3 was approximately $4.1 \AA$ when fully extended. This length is barely 
enough to accommodate one DNA base between dppz ligand of complex 3; the thickness of a DNA base is nearly $3.4 \AA$. Interactions of other structurally related bis-Ru(II) complexes with DNA have been reported. ${ }^{19,20}$ For instance, thorough spectroscopic and thermodynamic studies show that at least one of the two dppz units of the bis-Ru(II) complex, tethered by a 4,4'dipyridyl-1,5-pentane linker, intercalates between the DNA base pairs. ${ }^{19}$ The linker in this study, 4,4'-dipyridyl-1,3-propane, is significantly short. This fact may be the reason for violating the "nearest site exclusion" model. A schematic diagram of the bis-Ru(II) complex-DNA adduct, in which both the dppz ligands intercalate and one DNA base-pair is accommodated between dppz ligands, is depicted in Fig. 6. Although the Ru(II) metal is located in the minor groove in Fig. 6, the possibility of bis-intercalation from the major groove cannot be ruled out by this study.

Binding properties of complex 1 and 2 to DNA. The spectral properties of complexes $\mathbf{1}$ and $\mathbf{2}$ resemble each other. The magnitude of the $\mathrm{LD}^{\mathrm{r}}$ in the dppz ligand absorption region is less than half of complex $\mathbf{3}$ and is significantly smaller compared to that in the DNA absorption region. The average angle was $\sim 64^{\circ}$ relative to the DNA helical axis. The luminescence intensities of complexes $\mathbf{1}$ and $\mathbf{2}$ also increase upon binding to DNA. However, the intensity at the maximum is half that of complex $\mathbf{3}$. These changes in spectral properties of complexes $\mathbf{1}$ and $\mathbf{2}$, upon binding to DNA, do not seem to agree with the bis-intercalation model discussed for complex 3. Considering all spectral properties, the model in which one of the dppz ligand intercalates while the other remains exposed to the aqueous solvent may be suggestible. In this model, the intercalated dppz ligand orients as the DNA aligns in the flow, while that exposed to solvent does not, thereby not contributing to the LD signal. However, both dppz ligands absorb the radiation, which would result in a small $\mathrm{LD}^{\mathrm{r}}$, even though one of the dppz ligand intercalates. The fact that the luminescence intensities at all complex concentrations is about half of complex $\mathbf{3}$ may also be elucidated by this model; the concentration of the bound (intercalated) dppz ligand of complexes $\mathbf{1}$ and $\mathbf{2}$ was half that of complex $\mathbf{3}$. The lengths of the linkers in their full extension are $\sim 1.36$ and $3.85 \AA$ for complexes 1 and 2, respectively. Although the length of the linker of the complex $3,3.85 \AA$, is barely longer than the thickness of one base-pair, this would not be long enough to harbor the DNA base-pair. A binding mode, in which both of the dppz ligands lie at $\mathrm{a} \sim 64^{\circ}$ angle with respect to the DNA helical axis and are partially exposed to the solvent so as to result in half the intensity of the dppz ligand of complex 3 , may also fit the observed $L^{r}$ and the "light switch effect". However, this model is not conceivable because the similar orientations of the electric transition moments in the MLCT band and the binding stoichiometry cannot be explained by this model. Figure 6 shows a schematic diagram for the model in which one of the dppz ligand intercalates while the other dppz is exposed to solvent.

\section{Conclusions}

Both dppz ligands of the bis-Ru(II) complex $\mathbf{3}$ intercalate between DNA base pairs. Upon intercalation, the dppz ligand does not follow the "nearest site exclusion model", probably due to the short length of the linker. For the bis-Ru(II) complex with a shorter linker, one of the two dppz ligands conceivably intercalates while the other is exposed to the aqueous solvent.

Acknowledgments. This study was supported by an internal research grant provided by Yeungnam University.

\section{References}

1. Delaney, S.; Yoo, J.; Stemp, E.D.A.; Barton, J. K. Proc. Natl. Acad. Sci. USA 2004, 101, 10511-10516.

2. Youn, M.R.; Moon, S. J.; Lee, B.W.; Lee, D.-J.; Kim, J. M.; Kim, S.K.; Lee, C.-S. Bull. Korean Chem. Soc. 2005, 26, 537-542.

3. Lee, B. W.; Moon, S. J.; Youn, M. R.; Kim, J. H.; Jang, H. G.; Kim, S.K. Biophys. J. 2003, 85, 3865-3871.

4. Yun, B. H.; Kim, J. O.; Lee, B. W.; Lincoln. P.; Nordén, B.; Kim, J. M.; Kim, S. K. J. Phys. Chem. B 2003, 107, 9858-9864.

5. Greguric, A.; Greguric, I. D.; Hambley, T. W.; Aldrich-Wright, J. R.; Collins, J. G. Dalton Trans. 2002, 849-855.

6. Haq, I.; Lincoln, P.; Suh, D.; Nordén, B.; Chowdhry, B. Z.; Chaires, J. B. J. Am. Chem. Soc. 1995, 117, 4788-4796.

7. Hirot, C.; Lincoln, P.; Nordén, B. J. Am. Chem. Soc. 1993, 115, 3448-3454.

8. Jenkins, Y.; Freidman, A. E.; Turro, N. J.; Barton J. K. Biochemistry 1992, 31, 10809-10816.

9. Freidman, A. E.; Chambron, J.-C.; Sauvage, J.-P.; Turro, N. J.; Barton, J. K. J. Am. Chem. Soc. 1990, 112, 4960-4962.

10. Olson, E. J. C.; Hu, D.; Hörmann, A.; Jonkman, A. M.; Arkin, M. R.; Stemp, E. D. A.; Barton, J. K.; Barbara, P. F. J. Am. Chem. Soc. 1997, 119, 11458-11467.

11. Nair, R. B.; Cullum, B. M.; Murphy, C. J. Inorg. Chem. 1997, 36, 962-965.

12. Önfelt, B.; Lincoln, P.; Nordén, B.; Baskin, J. S.; Zewail, A. H. Proc. Natl. Acad. Sci. USA 2000, 97, 5708-5713.

13. Coates, C. G.; Olofsson, J.; Coletti, M.; McGarvey, J. J.; Önfelt, B.; Lincoln, P.; Nordén, B.; Tuite, E.; Matousek, P.; Parker, A. W. J. Phys. Chem. B 2001, 105, 12653-12664.

14. Coates, C. G.; McGarvey, J. J.; Callaghan, P. L.; Coletti, M.; Hamilton, J. G. J. Phys. Chem. B 2001, 105, 730-735.

15. Moon, S. J.; Kim, J. M.; Choi, J. Y.; Kim, S. K.; Lee, J. S.; Jang, H. G. J. Inorg. Biochem. 2005, 99, 994-1000.

16. Kim, J. M.; Lee, J.-M.; Choi, J. Y.; Lee, H. M.; Kim, S. K. J. Inorg. Biochem. 2007, 101, 1387-1393.

17. Önfelt, B.; Lincoln, P.; Nordén, B. Proc. Natl. Acad. Sci. USA 2000, 97, 5708-5713.

18. Önfelt, B.; Lincoln, P.; Nordén, B. J. Am. Chem. Soc. 2001, 123, 3630-3637.

19. Metcalfe, C.; Haq, I.; Thomas, J. A. Inorg. Chem. 2004, 43, 317 323.

20. Pierard, F.; Kirsh-De Mesmaeker, A. Inorg. Chem. Commun. 2006, 9, 111-126.

21. Wilhelmsson, L. M.; Westerlund, F.; Lincoln, P.; Nordén, B. J. Am. Chem. Soc. 2002, 124, 12092-12093.

22. Nordell, P.; Westerlund, F.; Wilhelmsson, L. M.; Nordén, B.; Lincoln, P. Angew. Chem. Int. Ed. 2007, 46, 2203-2206.

23. Jang, Y. J.; Kwon, B.-H.; Choi, B.-H.; Bae, C. H.; Seo, M. S.; Nam, W.; Kim, S. K. J. Inorg. Biochem. 2008, 102, 1885-1891.

24. Amouyal, E.; Homsi, A.; Chambron, J. C.; Sauvage, J. P. Chem. Soc. Dalton Trans. 1990, 1841-1845.

25. Nordén, B.; Kubista, M.; Kurucsev, T. Q. Rev. Biophys. Chem. 1992, 25, 51-170.

26. Nordén, B.; Kurucsev, T. J. Mol. Recognit. 1994, 7, 141-156.

27. Rodger, A.; Nordén, B. Circular Dichroism \& Linear Dichroism; Oxford University Press: New York, 1997.

28. Lincoln, P.; Anders, B.; Nordén, B. J. Am. Chem. Soc. 1996, 118 , 2644-2653. 